DOI: 10.14235/bs.2018.2145

Manuscript Type: Review

Turkish Title: Diyabet, Oksidatif Stres ve Endotel Disfonksiyonu

Turkish Running Head: Diyabet, Oksidatif Stres

Title: Diabetes, Oxidative Stress and Endothelial Dysfunction

Running Head: Diabetes, Oxidative Stress

Authors: Zeynep ÖZTÜRK

Institutions: İzmir Atatürk Eğitim ve Araştırma Hastanesi, Farmakoloji ve Toksikoloji Kliniği, İzmir, Türkiye

Address for Correspondence: Zeynep Öztürk dr.zeyneb@hotmail.com

Cite this article as: Öztürk Z. Diabetes, Oxidative Stress and Endothelial Dysfunction. Bezmialem Science 2018. DOI: 10.14235/bs.2018.2145

This article has been accepted for publication and undergone full peer review but has not been through the copyediting, typesetting, pagination and proofreading process, which may lead to differences between this version and the Version of Record. Please cite this article as: Öztürk Z. Diabetes, Oxidative Stress and Endothelial Dysfunction. Bezmialem Science 2018. DOI:

$10.14235 /$ bs.2018.2145

(C) Copyright 2018 by Bezmialem Vakif University - Available online at www.bezmialemscience.org 


\section{DİYABET, OKSIDATIIF STRES VE ENDOTEL DİSFONKSIYYONU}

\section{Özet}

Kardiyovasküler hastalıklar, diyabetik hastalarda en sık görülen morbidite ve mortalite nedenidir. Diyabette endotel disfonksiyonunda oksitadif stres önemli bir rol oynamaktadır. Oksidatif stres durumlarında, serbest oksijen radikalleri insülin direncini arttırıp pankreas beta hücrelerini de etkileyebilir. Diyabetin patogenezinin anlaşılmasında çeşitli deneysel modeller hayvanlarda oluşturulmakta olup özellikle yağlı diyet içerenler, insülin direnci oluşturduğundan tip 2 diyabeti en iyi taklit eden modellerdir. Diyabette lipid peroksidasyonunda da bir artış olduğu bilinmektedir. Bu durum yine oksidatif stresle ilişkilidir. Diyabette endotel disfonksiyonu, vazokonstrüksiyon ve vazodilatasyon arasında dengesizlikle kendini gösterir. Büyük boy arterlerde nitrik oksit, endotele bağlı gevşemede ana rolü üstlenmektedir. Nitrik oksidin anormal üretimi ya da yanıtının diyabette görülen vasküler ve endotel disfonksiyonuna katkıda bulunmaktadır. Oksidatif stres, nitrik oksit düzeylerini azaltır ve endotel bağımlı vazodilatasyonun bozulmasına neden olur. Bu nedenle son yıllarda diyabetik komplikasyonların tedavisine yönelik araştırmalar, antioksidan maddelere odaklanmıştır. Tedavide amaç oksidatif stresi, lipid ve glukoz düzeylerini düşürmektir. Böylelikle endotel disfonksiyonu iyileştirilip diyabete bağlı vasküler komplikasyonların önüne geçilebilir.

Anahtar Kelimeler: Antioksidan, diyabet, endotel disfonksiyonu, oksidatif stress

This article has been accepted for publication and undergone full peer review but has not been through the copyediting, typesetting, pagination and proofreading process, which may lead to differences between this version and the Version of Record. Please cite this article as: Öztürk Z. Diabetes, Oxidative Stress and Endothelial Dysfunction. Bezmialem Science 2018. DOI: 10.14235/bs.2018.2145 


\title{
DIABETES, OXIDATIVE STRESS AND ENDOTHELIAL DYSFUNCTION
}

\begin{abstract}
Cardiovascular diseases are the most common cause of morbidity and mortality in diabetic patients. Oxidative stress plays an important role in diabetic endothelial dysfunction. Free oxygen radicals may increase insulin resistance and affect pancreatic beta cells under conditions of oxidative stress. Several experimental animal models to understand the diabetes pathogenesis have been developed, and the model including high fat diet which leads to insulin resistance is the best animal model to mimic type 2 diabetes. In diabetes, it is well known that there is an increase in lipid peroxidation in diabetic cases. This condition is also associated with oxidative stress. Endothelial dysfunction creates imbalance between vasoconstriction and vasodilatation. In large arteries, nitric oxide plays a main role in endothelium-dependent vasodilatation. Abnormal production or response of nitric oxide contributes vascular and endothelial dysfunction in diabetes. Oxidative stress reduces the levels of nitric oxide and diminishes endothelium-dependent vasodilatation. In recent years, therefore, the studies to treat the diabetic complications have focused on antioxidant agents. The goal of the treatment is to decrease oxidative stress, as well as lipid and glucose levels. Thus, endothelial dysfunction may be ameliorated and diabetic vascular complications can be avoided.
\end{abstract}

Keywords: Antioxidant, diabetes, endothelial dysfunction, oxidative stress

This article has been accepted for publication and undergone full peer review but has not been through the copyediting, typesetting, pagination and proofreading process, which may lead to differences between this version and the Version of Record. Please cite this article as: Öztürk Z. Diabetes, Oxidative Stress and Endothelial Dysfunction. Bezmialem Science 2018. DOI:

$10.14235 /$ bs.2018.2145

(C) Copyright 2018 by Bezmialem Vakif University - Available online at www.bezmialemscience.org 


\section{GíRIŞ}

Diyabet sık görülen kronik seyirli bir metabolik hastalık olup karbonhidrat, yağ, protein ve elektrolit metabolizmasında bozukluklara yol açar. Kronik hiperglisemiyle seyreden, pankreastan insülin salgılanmasının eksikliği veya insülin etkisinin yetersizliği sonucu oluşan bir sendrom olarak da tanımlanabilir (1).

Diyabette insülinin kana salınımında azalma, kan glukozunun kullanımında azalma ve glukoz yapımında artma gibi faktörler kan glukoz düzeyinin yüksek kalmasına neden olabilir. Diyabette dolaşımdaki kanın glukoz seviyesinin yüksek olduğu düşünülürse, kalp ve damarlar başta olmak üzere, aslında tüm organ ve sistemlerin ilgilendiren bir patoloji söz konusudur. Böbrek yetmezliğinin, erişkin körlüklerin ve travma dışı alt ekstremite amputasyonlarının başta gelen nedeni, gelişmiş ülkelerde yapılan çalışmalara göre diyabettir (2).

Diyabetin tüm tiplerinde ana bulgu hiperglisemi olmakla birlikte, hiperglisemiye neden olan mekanizma farklıdır. Diyabet genel olarak Tip 1 ve Tip 2 olmak üzere iki alt gruba ayrılabilir (3). Tip 1 diyabet insülin salgılanmasında eksiklikle karakterize olup pankreas B hücrelerinin viral bir hasar, toksik veya otoimmün yıkımı nedeniyle gelişmektedir. Diyabet vakalarının \%10 kadarını oluşturan bu tip, juvenil diyabeti olarak da bilinir ve gelişme olasılığı ikinci dekadda artar (4). Tip 2 diyabet glikoz seviyelerine oranla yetersiz insülin sekresyonu ve periferal hedef dokuların insüline olan direnci ile karakterize edilmekte ve genellikle beta hücre fonksiyonunun kaybı ile gerçekleşmektedir. Hedef hücrelerdeki mevcut insülin reseptörlerinin sayısındaki bir azalma, insüline tepkinin olmamasına neden olabilir $(5,6)$.

This article has been accepted for publication and undergone full peer review but has not been through the copyediting, typesetting, pagination and proofreading process, which may lead to differences between this version and the Version of Record. Please cite this article as: Öztürk Z. Diabetes, Oxidative Stress and Endothelial Dysfunction. Bezmialem Science 2018. DOI: $10.14235 /$ bs.2018.2145 
Diyabetin sınıflaması, etiyolojisi ve patogenezinin giderek daha iyi anlaşılmasıyla, sürekli yenilenmektedir. İki ana diyabet tipinin dışında Dünya Sağlık Örgütü (WHO)

sınıflandırmasında malnütrisyonla ilișkili DM, bazı koşullar ve sendromlarla beraber olan Bozulmuş glukoz toleransı ile beraber olan tip, gebelik diyabeti (gestasyonel diyabet) gibi özel diyabet tipleri de sınıflandırılmaya başlanmıştır (7). Bu özel tipler içerisinde en sık görülen gebelik diyabeti olup tip 2 diyabete benzerdir ve bu tip diyabet şekli de insülin direnciyle ilgilidir. Gebelerde insülin direnci gebelik hormonları nedeniyle gelişmektedir.

Diyabetli hastalarda doku ve organlarda yapısal, biyokimyasal ve işlevsel bir çok değişiklik oluşur. Akut komplikasyonlar hayati tehlike oluşturabilir. Uzun dönemde oluşan damar patolojileri ise organlarda işlev kaybına neden olur. Erken evrede kan glukozunun kontrol altına alınması ile vasküler komplikasyonların ilerlemesi engellenebilir; koroner arter hastalığı, diyabetik nefropatinin önüne geçilebilir (8).

\section{Deneysel Diyabet Modelleri}

Deneysel hayvan modelleri, hastalıkların oluşum mekanizmalarının incelenmesi, hastalıktan korunma ve tedavi olanaklarının araştırılması için kullanılan yöntemlerdir. İlaç araştırmalarında in vivo deneylerin bir kısmı, mümkünse temsili hayvan modellerinde yapılır. Bazı modeller hayvanın diyetini değiştirmek veya toksik maddelerle belirli hedef organlarda lezyon yapmak suretiyle yapılır. Deneysel diyabet de pankreotektomi ya da pankreasin beta hücrelerinin tahrip edilmesiyle yapılabilmektedir. Hayvanlarda deneysel diyabet oluşturmak için fare, sıçan, tavşan, kobay, hamster, maymun, domuz, köpek ve kedi gibi deney hayvanları kullanılabilmektedir (Şekil 1). Deneysel diyabet, kimyasal ajanlarla $(9,10)$, spontan olarak $(11,12)$ veya virüs aracılığıyla (13) yapılabilmektedir. Günümüzde tanımlanmış pek çok deneysel hayvan modeli olmakla beraber bu modellerin hiç biri insan diyabetine tam olarak eşdeğer tutulamaz.

This article has been accepted for publication and undergone full peer review but has not been through the copyediting, typesetting, pagination and proofreading process, which may lead to differences between this version and the Version of Record. Please cite this article as: Öztürk Z. Diabetes, Oxidative Stress and Endothelial Dysfunction. Bezmialem Science 2018. DOI: $10.14235 /$ bs.2018.2145 
Obezitenin hızla artmasıyla dünya genelinde diyabet hastalığında da önemli bir artış olmuştur ve tip 2 diyabet bunların \%95'ini oluşturmaktadır. Bu nedenle tip 2 diyabet tedavisine yönelik yeni yaklaşımlar geliştirmek ve daha iyi yöntemler bulmak gerekmektedir. Tip 2 diyabete bağlı komplikasyonların, risklerin önüne geçmek için deneysel çalışmalar yapılmakta ve bu yolla vasküler ve nöronal lezyonların patogenezi, terapötik ajanların etki mekanizmaları aydınlatılmaya çalışılmaktadır. Bu konuda çeşitli hayvan çalışma modelleri de bulunmasına rağmen, genellikle bunlar tip 2 diyabetin seyri ve insandaki kliniğiyle pek uyum sağlamamaktadır. Bu nedenle araştırmacılar tip 2 diyabet için yeni hayvan modelleri ya da kombine modeller oluşturma gayreti içerisindedirler. Başarılı bir model ucuz, kolay uygulanabilir ve tip 2 diyabet tedavisine yönelik, pratik olarak kolay test edilebilir parametreleri içermelidir.

Tip 2 diyabetin önemli bir özelliği olan insülin direnci oluşturulmasında yüksek yağ içerikli diyetin (HFD- high fat diet) oldukça iyi bir yol olduğu düşünülmektedir. Çeşitli çalışmalar sıçanlarda HFD ile beslenmenin net olarak hiperglisemi ya da diyabet oluşturmasa da insülin direnci oluşturduğunu bildirmektedir (14- 17). Streptozotosin (STZ), deneysel diyabet oluşturmak üzere hayvanlarda en çok kullanılan ajandır. STZ, pankreas $\beta$ hücrelerinde ölüme neden olur. STZ yüksek dozlarda insülin salınımı şiddetli olarak bozar ve tip 1 diyabete benzer bir tablo oluşturur. STZ' in düşük dozlarının ise insülin salınımında 1lımlı bir bozulmaya neden olduğu bilinmektedir ve bu da tip 2 diyabetin geç dönemiyle benzerlik göstermektedir $(19,20)$.

Tüm bunlardan yola çıkılarak, HFD ve bunu izleyen düşük doz STZ uygulamasına yönelik, tip 2 diyabetin metabolik karakteristikleri ile hastalığın doğal seyrine uygun yeni bir sıçan modeli oluşturulmaya çalışılmıştır. Son yıllarda bu model ile yapılan diyabet çalışmaları oldukça fazladır (14, 18-21).

Bu kombinasyonun dışında tekrarlı düşük doz STZ uygulamasının yapılabileceğini bildiren çalışmalar da vardır. Diyabet oluşturulmak üzere çalışılan sıçanlarda, tek yüksek doz STZ uygulaması yerine tekrarlı düşük doz STZ uygulamasının beta hücrelerinde kademeli ve otoimmün bir yıkıma yol açıyor olabileceği bildirilmiştir (21- 23).

This article has been accepted for publication and undergone full peer review but has not been through the copyediting, typesetting, pagination and proofreading process, which may lead to differences between this version and the Version of Record. Please cite this article as: Öztürk Z. Diabetes, Oxidative Stress and Endothelial Dysfunction. Bezmialem Science 2018. DOI: $10.14235 /$ bs.2018.2145 


\section{Diyabet ve Oksidatif Stres}

İnsan hayatı için oksijen çok önemli ve gerekli olmasına karşın, ekzojen ve endojen bazı reaktif oksijen türleri organizmaya zarar verme potansiyeline sahiptir (24). Pek çoğu serbest radikal olan reaktif oksijen türleri, kimyasal reaktivitesi yüksek oksijen formlarıdır. Oksijenin dış yörüngesine bir veya daha fazla eşleşmemiş elektron eklenmesiyle serbest oksijen radikaline dönüşür. Bu bileşikler de son yörüngelerinde ortaklanmamış elektron içerdikleri için kolayca diğer moleküllerle reaksiyona girerek onları tahrip edebilen bileşikler oluştururlar ve organizmada çok etkili bir hasar meydana getirirler (25). Protein, lipid, DNA ve nükleotid koenzimler gibi birçok biyolojik materyale zarar verebilirler. Bu zararın yaşlanmayı teşvik ettiği ve ayrıca kalp damar hastalıkları, çeşitli kanser türleri, katarakt, bağışıklık sisteminde zayıflama, sinir sistemi dejeneratif hastalıkları gibi birçok hastalığa sebep olduğuna dair bilgiler bulunmaktadır (26). Canlı hücrelerdeki oksijen metabolizması, çevre kirleticileri, radyasyon, pestisitler gibi birçok etmen kaçınılmaz bir şekilde oksijen türevi serbest radikallerin oluşumuna yol açmaktadır. Bu radikallerin başlıcaları; tekli oksijen, süperoksit anyonu, hidroksi, peroksi ve alkoksi radikalleridir. Reaktif oksijen türlerinin zararlarına karşılık vücuttaki farklı doğal savunma sistemleri serbest radikalleri kontrol altında tutmaktadır (Tablo 1). Serbest radikallere bağlı oluşan oksidasyon olaylarını engelleyen, serbest radikalleri stabilize etme yeteneğindeki maddeler antioksidan olarak adlandırılmaktadır (27). Antioksidanlar mekanizmalarına göre, primer ve sekonder antioksidanlar olmak üzere ikiye ayrılmaktadır. Primer antioksidanlar; radikallerle reaksiyona girerek bunların daha zararlı formlara dönüşmelerini ve yeni serbest radikal oluşumunu önleyen bileşiklerdir. Bu kategoride yer alan süperoksit dismutaz, glutatyon peroksidaz ve katalaz gibi enzim sistemleri serbest radikalleri yok etme yeteneğindedir. Bu enzimler genel olarak serbest radikallerin DNA, proteinler ve lipidler gibi hücresel bileşenlere zarar vermesini sınırlandırmak suretiyle bir hücresel bölgeden diğerine geçişini de önleyebilmektedirler (24). Sekonder antioksidanlar ise; oksijen radikalini yakalayan ve radikal zincir reaksiyonlarını kıran E vitamini, C vitamini, bilirubin, ürik asit, ve polifenoller gibi bileşiklerdir.

This article has been accepted for publication and undergone full peer review but has not been through the copyediting, typesetting, pagination and proofreading process, which may lead to differences between this version and the Version of Record. Please cite this article as: Öztürk Z. Diabetes, Oxidative Stress and Endothelial Dysfunction. Bezmialem Science 2018. DOI: $10.14235 /$ bs.2018.2145 
Diyabetik komplikasyonlarının çıkmasında oksidatif stres önemli bir mekanizma olarak tarif edilmektedir (28). Serbest radikallerin oluşum hızı ile bunların ortadan kaldırılma hızı bir denge içerisindedir ve bu dengeye oksidatif stabilite denir. Oksidatif stabilitenin bozulduğu durumlarda organizma, serbest radikallerden etkilenmektedir. Serbest radikallerin ortadan kaldırılma hızında bir düşme ya da oluşum hızında artma buna neden olabilir. Oksidatif stres denilen bu durum antioksidan savunma mekanizması ile serbest radikal oluşumu arasındaki önemli dengesizliği göstermekte olup doku hasarıyla sonuçlanmaktadır.

Diyabette oksidatif stresi arttıran mekanizmalar, nonenzimatik glikozilasyon, otooksidatif glikozilasyon, sorbitol yolu aktivitesi, enerji metabolizmasındaki değişikliklerden kaynaklanan metabolik stres, inflamatuar mediatörlerin düzeyleri, antioksidan savunma sistemindeki değişiklikler sonucu oluşan doku hasarıdır (29).

Hiperglisemide hücre içerisinde serbest radikaller üretilmektedir. Pankreas beta hücreleri, oksidatif strese en duyarlı yapılardan biridir ve burada oluşan hasarın hipergliseminin toksik bir etkisi olduğu düşünülmektedir. Pankreas adacık hücrelerinde glutatyon peroksidaz, süperoksit dismutaz, katalaz gibi antioksidan enzimlerin ekspresyonları, diğer dokularla karşılaştırıldığında en düşük düzeydedir (30). STZ ile diyabet oluşturulmuş ratlarda, bir oksidatif hasar endeksi olarak yaygın kullanılmakta olan malondialdehid (MDA) ile glutatyon peoksidaz seviyelerinin karaciğer, böbrek ve mitokondrilerinde arttığını bildirilmiştir. Diyabetik ratların böbreklerinde de MDA seviyelerinin arttığı gösterilmiştir.

Hidrojen peroksit, yüksek reaktiviteye sahip bir reaktif oksijen türü ürünü olan hidroksil radikaline dönüşmektedir. Diyabette insülin reseptör sinyal yolağında ve sinyal transdüksiyonu üzerinde hidroksil radikalinin önemli bir etkisi olduğu düşünülmektedir (31).

This article has been accepted for publication and undergone full peer review but has not been through the copyediting, typesetting, pagination and proofreading process, which may lead to differences between this version and the Version of Record. Please cite this article as: Öztürk Z. Diabetes, Oxidative Stress and Endothelial Dysfunction. Bezmialem Science 2018. DOI: $10.14235 /$ bs.2018.2145 
Yapılan çeşitli hücre kültürü çalışmalarında, endotel ve düz kas hücreleri yüksek konsantrasyonda glukoz içeren bir ortamda inkübe edildiğinde serbest radikal oluşumu gözlenmiştir (30). Deneysel diyabet modeli oluşturmak üzere kullanılan streptozosinin de pankreası harap ederken oksidatif stres oluşturduğu ve nitrik oksid (NO) yanıtlarını bozarak diyabete yol açtığına dair kanıtlar vardır (31).

Yalnızca kan şekeri yüksekliği değil, kanda trigliserid düzeylerinin de yüksek olmasının diyabetik komplikasyonlar açısından önemli bir risk olduğu düşünülmektedir (32). Lipid peroksidasyonunun bu ilişkide önemli olduğu husunda görüş birliği vardır. Diyabette çeşitli dokularda lipid peroksidasyonunun arttığına dair kanıtlar vardır. Lipid peroksidasyonu, enzimatik olarak lipooksijenaz yolu ile prostoglandinlerden ya da serbest radikaller etkisi ile endotelyal ve fagositik hücrelerin membranlarında bulunan lipidlerden nonenzimatik yolla oluşabilir.

Bunun yanı sıra vasküler komplikasyonları gelişmiş diyabetik vakalarda, LDL oksidasyonunda da hiperglisemiye bağlı bir artış gösterilmiştir. Bunlara ek olarak protein oksidasyonu da gösterilmiş olup özellikle myelin, elastin ve kollajende gerçekleşen oksidasyon olayları sonucunda ateroskleroz, katarakt, anjiyopati ve nefropati gibi diyabetik komplikasyonların oluştuğu düşünülmektedir (33).

This article has been accepted for publication and undergone full peer review but has not been through the copyediting, typesetting, pagination and proofreading process, which may lead to differences between this version and the Version of Record. Please cite this article as: Öztürk Z. Diabetes, Oxidative Stress and Endothelial Dysfunction. Bezmialem Science 2018. DOI: 


\section{Diyabet ve Endotel Disfonksiyonu}

Kardiyovasküler hastalıklar, diyabetik hastalarda en önemli morbidite ve mortalite nedenidir. Diyabete bağlı damarlarda meydana gelen bu değişimler, tutulan damarın büyüklüğüne göre, mikro veya makroanjiopati olarak adlandırılır. Böbrek damarlarının tutulumuna renal mikroanjiopati denir ve diyabetik nefropatide önemli rol oynar. Aynı şekilde retinal mikroanjiopatiye de diyabetik retinopatiye, vaso nervorumların mikroanjiyopatisi ise diyabetik nöropatiye sebep olur. Diyabetik hastalardaki makroanjiopati ise aterosklerozun ileri bir şekli olup, koroner, karotis ve periferik arterleri etkileyerek miyokard enfarktüsü riskini artırır, inme ve diyabetik ayak gelişimine neden olur (34).

Diyabette gelişen mikrovasküler anjiyopatilerde en önemli etken yüksek kan şekeridir (35). Bunun yanı sıra obezite, tansiyon yüksekliği, sigara, hiperkolesterolemi, dislipidemi gibi faktörler de mikroanjiopatiye neden olabilmektedir. Makroanjiyopatide ise kan şekeri yüksekliğinden ziyade mikroanjiyopatiye de neden olabilen diğer risk faktörleri ön plana çıkmaktadır. Bu risk faktörleri inflamasyon ve endotel disfonksiyonuna ve bunun sonucu olarak damar duvarında ilerleyici bir hasarına yol açar. Mikro ve makroanjiyopati oluşumunda endotel disfonksiyonun öneminin ortaya konmasını takiben yapılan çalışmalar bu konuya odaklanmıştır (36).

Endotel, basitçe damar iç katmanı olup damar fonksiyonlarının düzenlenmesinde anahtar rol oynamaktadır. Endotelin herhangi bir nedenle oluşan hasara bağlı fonksiyon görememesine endotel disfonksiyonu denir (37). Hiperkolesterolemi, dislipidemi, sigara kullanımı ve diyabet gibi faktörler endotel disfonksiyonuna neden olabilecek risk faktörleri arasındadır. Diyabetik olgularda gelişen retinopati, nefropati ve ateroskleroz gelişimi endotel disfonksiyonuyla ilişkilidir.

This article has been accepted for publication and undergone full peer review but has not been through the copyediting, typesetting, pagination and proofreading process, which may lead to differences between this version and the Version of Record. Please cite this article as: Öztürk Z. Diabetes, Oxidative Stress and Endothelial Dysfunction. Bezmialem Science 2018. DOI: $10.14235 /$ bs.2018.2145 
Yüksek yağlı diyet (HFD), hiperkolesterolemiye oluşturarak arter duvarlarında kolesterol depolanmasına yol açabilir. Yağlı dejenerasyon (ateroz) ve damar daralması (skleroz) birlikteliğinin bir sonucu olarak ateroskleroz oluşmaktadır. Aterosklerozun endotele bağ 1 vazodilatasyonu deneysel hayvan modellerinde (38) ve insanlarda (39) bozduğu gösterilmiş olup vazokonstrüksiyona ve damar spazmına yol açabileceği düşünülmektedir. Pek çok çalışma vasküler gevşeme yanıtının endotelden kaynaklanan relaksasyon faktörü (EDRF) aracılığıyla olduğunu göstermiştir (40). Daha sonraları EDRF'nin NO ile aynı madde olduğu bildirilmiştir (41).

Endotel disfonksiyonunun patofizyolojisi karmaşıktır ve çeşitli mekanizmalar yoluyla olusabilir. Bu mekanizmalardan belki de en önemlisi endotelden NO salınımında azalmadır. NO endotelden salınan en önemli vazodilatatör maddedir. Vazodilatasyon yanında düz kas hücrelerinin büyümesini ve inflamasyonu inhibe eder, aynı zamanda antiagregan etkileri de vardır. NO düzeylerinde azalmanın endotel disfonksiyonu ile iliskili oldugu pek çok çalışmada rapor edilmiştir. Bu durum endotelyal NO sentetaz (eNOS) enziminin aktivitesinin azalmasından veya NO in biyolojik aktivitesinde azalmadan kaynaklanabilir. Serbest oksijen radikallerinin (SOR) NO ile reaksiyona girerek peroksinitrit olusumuna neden olduğu, bu sitotoksik oksidanın da proteinlerin nitrasyonu yoluyla hücresel proteinlerin fonksiyonunu bozarak endotel disfonksiyonuna yol açtı̆̆ 1 bilinmektedir. Peroksinitrit, LDL nin oksidasyonuna yol açarak proaterojenik rol oynar. Aynı zamanda eNOS'un kofaktörü olan tetrahidrobiopterin ile etkileşerek eNOS aktivitesini azaltır. Oksidatif stres artışı eNOS enziminin redüktaz fonksiyonunu aktif hale geçirerek daha fazla SOR oluşumuna neden olur. SOR de damar duvarında proinflamatuar olayları başlatır.

SOR adezyonu (vasküler hücre adezyon molekülü; VCAM-1 ve interselüler adezyon molekülü; ICAM-1) ve kemotaktik molekülleri (makrofaj kemotaktik peptid; MCP-1) arttırır. İnflamasyonun başlaması NO'in aktivitesini azaltır. C reaktif proteinin (CRP) de eNOS aktivitesini azalttığ 1 gösterilmiştir (42).

Oksidatif stres, NO düzeylerini azaltır ve endotel bağımlı vazodilatasyonun bozulmasına neden olur. Kronik renal yetmezlikli hastalarda da oksidatif stres belirteçlerinin endotel fonksiyonlarının bozulmasıyla arttığı gösterilmiştir. SOR'nin ayrıca apoptozise yol açarak endotel hasarını tetiklediği düşünülmektedir (42).

This article has been accepted for publication and undergone full peer review but has not been through the copyediting, typesetting, pagination and proofreading process, which may lead to differences between this version and the Version of Record. Please cite this article as: Öztürk Z. Diabetes, Oxidative Stress and Endothelial Dysfunction. Bezmialem Science 2018. DOI: 10.14235/bs.2018.2145 
NO azalmasına yol açan bir diğer mekanizma eNOS enziminin endojen kompetitif inhibitörü olan asimetrik dimetil arjinin (ADMA) düzeylerindeki artıştır. ADMA protein katabolizması sırasında ortaya çıkan bir üründür, böbrekler yoluyla veya sitrülline metabolize edilerek elimine edilir. Kronik renal yetmezlikli hastalarda eNOS inhibisyonunun artmış plazma ADMA düzeyleri ile ilişkili olduğu gösterilmiştir. Hiperkolesterolemik bireylerde ADMA düzeylerindeki artış ile endotele bağımlı vazodilatasyon arasında negatif korelasyon bulunmuş, eNOS enziminin substratı ve ADMA'nın kompetitif inhibitörü olan L-arjinin infüzyonunun endotel fonksiyonlarını düzelttiği gösterilmiştir (42).

Diyabette endotel disfonksiyonu, vazokonstrüksiyon ve vazodilatasyon arasında dengesizlikle kendini gösterir. Büyük boy arterlerde NO, endotele bağlı gevşemede ana rolü üstlenmektedir. NO'in anormal üretimi ya da yanıtının diyabette görülen vasküler ve endotel disfonksiyonuna katkıda bulunmaktadır.

NO, nitrik oksit sentaz (NOS) aracılığıyla, L-arjinin amino asidinin guanido nitrojeninin oksitlenmesi sonucu oluşur. Stabil olmayan bir madde olup nitrit ve nitrata indirgenir. Sentez için nikotinamid adenin dinükleotid fosfat (NADPH), kalmodulin, oksijen ve kofaktör olarak hem, flavin, mononükleotid, flavin adenin dinükleotid ve tetrahidrobiyopterin gereklidir. NO sentezine aracı olan NOS enziminin nöronal, endotelyal ve immünolojik olmak üzere üç farklı izoformu vardır. Bunlardan nöronal ve endotelyal izoformlar, yapısal NO-sentaz (cNOS) şeklinde isimlendirilmiştir (43).

Hiperglisemi, NO oluşumu ve fonksiyonunu etkiler; ayrıca süperoksit oluşumunu artırmaktadır. Diyabette endotel disfonksiyonuna süperoksit ve NO üretimi arasındaki dengesizliğin yol açtığı düşünülmektedir (44). Süperoksit, NO’i peroksinitrite dönüştürerek inaktive eder; böylelikle NO oluşumu ve biyoyararlanımı azaltır. Diyabetin vasküler komplikasyonlarının tedavisinde hedef, NO oluşumu ve biyoaktivitesini arttırmak ve reaktif oksijen radikallerinin oluşumu azaltmak olmalıdır.

This article has been accepted for publication and undergone full peer review but has not been through the copyediting, typesetting, pagination and proofreading process, which may lead to differences between this version and the Version of Record. Please cite this article as: Öztürk Z. Diabetes, Oxidative Stress and Endothelial Dysfunction. Bezmialem Science 2018. DOI: $10.14235 /$ bs.2018.2145 
Diyabetik sıçanlarda koroner arterlerde, asetilkolinle oluşan damar gevşemesindeki düşüşlerin, plazma NO seviyelerinde ve eNOS protein ekspresyonundaki azalma ile birlikte olduğu gösterilmiştir (45). Streptozotosinle diyabet oluşturulmuş sıçanların torasik aortlarında benzer bir sonuç elde edilmiştir (20). Endotel NOS, endotelde NO sentezini sağlamaktadır. İnsülin rezistans ve diyabetik sıçanlarda endotel NO sentezi ve vazodilatasyon önemli ölçüde bozulmuştur. Diyabetik sıçanlarda eNOS ekspresyonu azaldığı gösterilmiştir.

\section{SONUÇ}

Diyabete bağlı vasküler komplikasyonların gelişiminden endotel disfonksiyonu sorumludur. Endotel disfonksiyon gelişimi, oksidatif stres ve buna bağlı oluşan bir patolojik sürecin sonucudur. Oksidatif stres kaynaklarını azaltmak ve antioksidan tedaviler de diyabette endotel disfonksiyonu gelişimini önleyerek ağır komplikasyonların önüne geçmede yardımcı olabilir. Yeni tedavi alternatiflerinin oluşturulabilmesi açısından fizyopatolojik sürecin iyi bilinmesi önem taşımakta olup bu konuda hem deneysel hem de epidemiyolojik çalışmalara gereksinim oldukça fazladır.

This article has been accepted for publication and undergone full peer review but has not been through the copyediting, typesetting, pagination and proofreading process, which may lead to differences between this version and the Version of Record. Please cite this article as: Öztürk Z. Diabetes, Oxidative Stress and Endothelial Dysfunction. Bezmialem Science 2018. DOI:

$10.14235 /$ bs.2018.2145 


\section{KAYNAKLAR}

1. Larner J. Insulin and oral hypoglysemic drugs, glucagon. In: Gilman AG, Goodman LS, Rall TW, Murad F, editors. Goodman and Gilmans the pharmacological basis therapeutics. New York: MacMillan Publ. Comp; 1985.p.1490-516.

2. Özata M. and Yöntem A. Endokrinoloji metabolizma ve diabet. 1st ed. Istanbul: Istanbul Medikal; 2006.

3. Satman I, Yilmaz T, Sengül A, Salman S, Salman F, Uygur S, et al. Population-based study of diabetes and risk characteristics in Turkey: results of the turkish diabetes epidemiology study (TURDEP). Diabetes Care. 2002; 25: 1551-6.

4. Wilson JD, Foster DW, Kronenberg HM, Larsen PR. Williams Textbook of Endocrinology. 9th ed. Philadelphia: WB. Saunders Company; 1998.

5. Scarlett JA, Gray RS, Griffin J, Olefsky JM, Kolterman OG. İnsülin teatment reverses the insülin resistance of type II diabetes mellitus. Diabetes Care. 1982; 5: 353-63.

6. Wing RR, Blair EH, Bononi P, Marcus MD, Watanabe R, Bergman RN. Caloric restriction per se is a significant factor in improvements in glycemic control and insulin sensitivity during weight loss in obese NIDDM patients. Diabetes Care. 1994; 17: 30-6.

7. Roden M. Diabetes mellitus: definition, classification and diagnosis. Acta Med Austriaca. 2004; 31: 156-7.

8. Kannel WB. Contribution of the Framingham Study to the Coquest of Coronary Artery Disease. Am. J. Cardiol; 1988; 62: 1109-12.

This article has been accepted for publication and undergone full peer review but has not been through the copyediting, typesetting, pagination and proofreading process, which may lead to differences between this version and the Version of Record. Please cite this article as: Öztürk Z. Diabetes, Oxidative Stress and Endothelial Dysfunction. Bezmialem Science 2018. DOI: $10.14235 /$ bs.2018.2145 
9. Dunn JS, Duffy E, Gilmour MK, Kirkpatrick J, McLetchie NGB. Further observations on the effects of alloxan on the pancreatic islets. J Physiol 1944;103:233-43.

10. Pushparaj P, Tan $\mathrm{CH}$, Tan BKH. Effects of Averrhoa bilimbi leaf extract on blood glucose and lipids in streptozotocin diabetic rats. J Ethnopharmacol 2000; 72: 69-76.

11. Kohnert KD, Axcrona UM, Hehmke B, Klöting I, Sundler F, Ahrén B. Islet neuronal abnormalities associated with impaired insulin secretion in type 2 diabetes in the Chinese hamster. Regul Pept 1999; 82: 71-9.

12. Chang AY, Perry CS. Acid glycohydrolase in Chinese hamster with spontaneous diabetes: iv. Diabetes and line dependent variation in plasma enzyme activity. Diabetologia 1978; 15: 423-9.

13. Ejrnaes M, Von Errath MG, Christen U. Cure of chronic viral infection and virusinduced type 1 diabetes by neutralizing antibodies. Clin Dev Immunol 2006; 13: 67-77.

14. K. Sahin, M. Onderci, M. Tuzcu, Ustundag B, Cikim G, Ozercan IH, et al. Effect of chromium on carbohydrate and lipid metabolism in a rat model of type 2 diabetes mellitus: the fat-fed, streptozotocin-treated rat. Metabolism 2007; 56: 1233-40.

15. Zhao S, Chu Y, Zhang C, Lin Y, Xu K, Yang P, et al. Diet-induced central obesity and insulin resistance in rabbits. Journal of Animal Physiology and Animal Nutrition 2008; 92 : $105-11$.

16. Tanaka S, Hayashi T, Toyoda T, Hamada T, Shimizu Y, Hirata M, et al. High-fat diet impairs the effects of a single bout of endurance exercise on glucose transport and insulin sensitivity in rat skeletal muscle. Metabolism 2007; 56: 1719-28.

This article has been accepted for publication and undergone full peer review but has not been through the copyediting, typesetting, pagination and proofreading process, which may lead to differences between this version and the Version of Record. Please cite this article as: Öztürk Z. Diabetes, Oxidative Stress and Endothelial Dysfunction. Bezmialem Science 2018. DOI: $10.14235 /$ bs.2018.2145 
17. Flanagan AM, Brown JL, Santiago CA, Aad PY, Spicer LJ, Spicer MT. High-fat diets promote insulin resistance through cytokine gene expression in growing female rats. $\mathrm{J}$ Nutr Biochem 2008; 19: 505-13.

18. Reed MJ, Meszaros K, Entes LJ, Claypool MD, Pinkett JG, Gadbois TM, et al. A new rat model of type 2 diabetes: the fat-fed, streptozotocin-treated rat. Metabolism 2000; 49: $1390-4$.

19. Srinivasan K, Viswanad B, Asrat L, Kaul CL, Ramarao P. Combination of high-fat diet-fed and low-dose streptozotocin-treated rat: a model for type 2 diabetes and pharmacological screening. Pharmacol Res 2005; 52: 313-20.

20. Oztürk Z, Gurpinar T, Vural K, Boyacioglu S, Korkmaz M, Var A. Effects of selenium on endothelial dysfunction and metabolic profile in low dose streptozotocin induced diabetic rats fed a high fat diet. Biotech Histochem 2015; 90: 506-15.

21. Ozturk Z. High-fat diet and low-dose streptozotocin induced type 2 diabetes: a methodological critique. Appl Med Res 2016; 2: 41-2.

22. Kannan Y, Tokunaga M, Moriyama M, Kinoshita H, Nakamura Y. Beneficial effects of troglitazone on neutrophil dysfunction in multiple low-dose streptozotocin-induced diabetic mice. Clin Exp Immunol 2004; 137: 263-71.

23. Howarth FC, Qureshi A, Shahin A, Lukic ML. Effects of single high-dose and multiple low-dose streptozotocin on contraction and intracellular $\mathrm{Ca} 2+$ in ventricular myocytes from diabetes resistant and susceptible rats. Mol Cell Biochem 2005; 269: 103-8.

24. Diplock A. Healty lifestyles nutrition and physical activity: Antioxidant nutrients. ILSI Europe concise monograph series, Belgium, 1998; 59.

25. Halliwell B, Gutteridge JMC. Role of free radicals and catalytic metal ions in human disease. Methods Enzymol 1990; 186: 1-85.

This article has been accepted for publication and undergone full peer review but has not been through the copyediting, typesetting, pagination and proofreading process, which may lead to differences between this version and the Version of Record. Please cite this article as: Öztürk Z. Diabetes, Oxidative Stress and Endothelial Dysfunction. Bezmialem Science 2018. DOI: $10.14235 /$ bs. 2018.2145 
26. Meydani M. Antioxidants and cognitive function. Nutr Rev 2001; 59: 75-82.

27. Elliot JG. Application of antioxidant vitamins in foods and beverages. Food Tech 1999; 53: 46-8.

28. Giugliano D, Ceriello A, Paolisso G. Oxidative stress and diabetic vascular complications. Diabetes Care 1996; 19: 257-67.

29. King GL, Banskota NK. Mechanism of diabetic microvascular complications. In: Kahn CR, Weir GC, King GL, Jacobson AM, Moses AC, Smith RJ, editors. Joslin's Diabetes Mellitus. Philedephia: Lippincott Williams \& Wilkins; 1994. p. 634- 48.

30. Robertson RP, Harmon J, Tran PO, Poitout V. Beta-cell glucose toxicity, lipotoxicity, and chronic oxidative street in type 2 diabetes. Diabetes 2004; 53: 119-24.

31. Houslay MD. 'Crosstalks': a pivotal role for protein kinase C in modulating relationships between signal transduction pathways. Eur J Biochem 1991; 195: 9-27.

32. Battist WP, Palmisano J, Keane WF. Dyslipidemia in patients with type 2 diabetes. Relationships between lipids, kidney disease and cardiovascular disease. Clin Chem Lab Med 2003; 41: 1174-81.

33. Dean RT, Fu S, Stocker R, Davies MJ. Biochemistry and Pathology of Radicalmediated Protein Oxidation. Biochem J 1997; 324: 1-18.

34. Dillmann WH. Diabetes and thyroid- hormone induced changes in cardiac function and their molecular basis. Annu Rev Med 1989; 40: 373-94.

35. Duby JJ, Campbell RK, Seter SM, White JR, Rasmussen KA. Diabetic neuropathy:an intensive review. Am J Health Syst Pharm 2004; 61: 160- 73.

36. Tesfamariam B. Free radicals in diabetic endothelial cell dysfunction. Free Radic Biol Med 1994; 16: 383-91.

This article has been accepted for publication and undergone full peer review but has not been through the copyediting, typesetting, pagination and proofreading process, which may lead to differences between this version and the Version of Record. Please cite this article as: Öztürk Z. Diabetes, Oxidative Stress and Endothelial Dysfunction. Bezmialem Science 2018. DOI: $10.14235 /$ bs.2018.2145 
37. Endemenn DH, Schriffrin EL. Endothelial dysfunction. J Am Soc Nephrol 2004; 15: 1983-92.

38. Jayakody RL, Thomson ABR, Kappagoda CT. Cholesterol feeding impairs endothelium dependent relaxation of rabbit aorta. Can J Physiol Pharmacol 1985; 63: 1206-9.

39. Förstermann U, Mügge A, Alheid U, Haverich A, Frölich JC. Selective attenuation of endothelial mediated vasodilation atherosclerotic human coronary arteries. Circ Res 1988; 62: $185-90$.

40. Furchgott RF. The role of endothelium in the responses of vascular smooth muscle to drugs. Ann Rev Pharmacol Toxicol 1984; 24: 175-97.

41. Palmer RMJ, Ferrige AG, Moncada S. Nitric oxide release accounts for the biological activity of endothelium derived relaxing factor. Nature 1987; 327, 524-6.

42. Altan N, Sepici-Dincel A, Koca C. Diabetes mellitus ve Oksidatif Stres. Turk J Biochem 2006; 31: 51-6.

43. Takahashi Y, Nakano T, Wakabayashi I. Increased induction of inducible nitric oxide synthase expression in aortae of type 2 diabetes rats. J Pharmacol Sci 2008; 107: 190-200.

44. Srinivasan S, Hatley ME, Bolick DT, Palmer LA, Edelstein D, Brownlee M, et al. Hyperglycaemia-induced superoxide production decreases eNOS expression via AP-1 activation in aortic endothelial cells. Diabetologia 2004; 47: 1727-34.

45. Tawfik HE, El-Remessy AB, Matragoon S, Ma G, Caldwell RB, Caldwell RW. Simvastatin improves diabetes-induced coronary endothelial dysfunction. J Pharmacol Exp Ther 2006; 319: 386-95.

This article has been accepted for publication and undergone full peer review but has not been through the copyediting, typesetting, pagination and proofreading process, which may lead to differences between this version and the Version of Record. Please cite this article as: Öztürk Z. Diabetes, Oxidative Stress and Endothelial Dysfunction. Bezmialem Science 2018. DOI: $10.14235 /$ bs.2018.2145 
TABLOLAR

Tablo 1. Oksidan Kaynaklar ve Antioksidan Savunma Sistemleri

\begin{tabular}{|l|l|}
\hline \multicolumn{1}{|c|}{ Oksidanlar } & \multicolumn{1}{c|}{ Antioksidan Savunma } \\
\hline Sigara dumanı & Süperoksid dismutaz \\
Çevre kirleticiler & Katalaz \\
Radyasyon & Glutatyon peroksidaz \\
Karsinojenler & Glutatyon \\
Pestisidler & Selenyum \\
Egzersiz & E vitamini \\
Ateşli hastalıklar & C vitamini \\
İskemi & Ubikinon \\
diyet & Ürik asit \\
\hline
\end{tabular}

This article has been accepted for publication and undergone full peer review but has not been through the copyediting, typesetting, pagination and proofreading process, which may lead to differences between this version and the Version of Record. Please cite this article as: Öztürk Z. Diabetes, Oxidative Stress and Endothelial Dysfunction. Bezmialem Science 2018. DOI: $10.14235 /$ bs.2018.2145 


\section{ŞEKİL AÇIKLAMALARI}

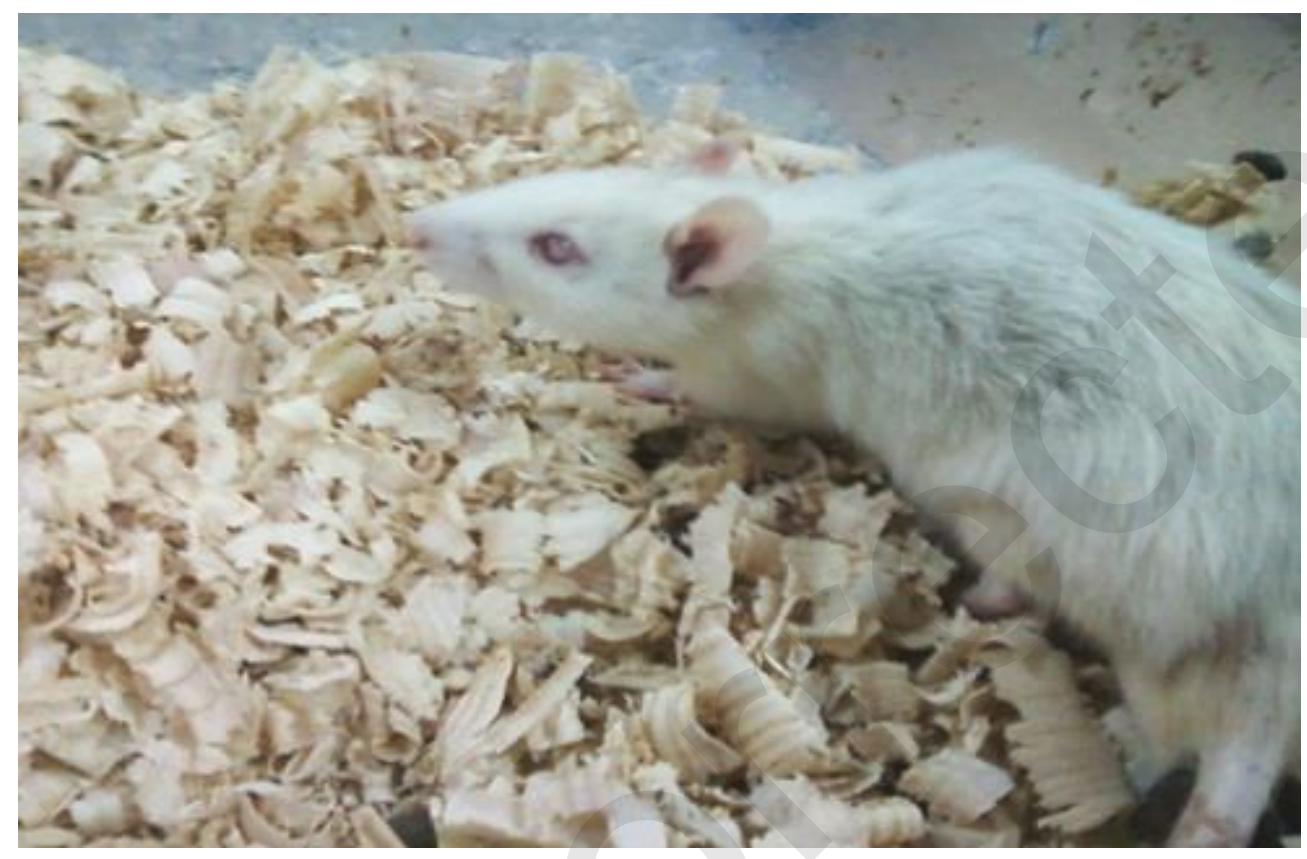

Şekil 1.1 Tedavi almamış diyabetik sıçan dış görünüşü, belirgin kilo kaybı ve gözde katarakt oluşumu

This article has been accepted for publication and undergone full peer review but has not been through the copyediting, typesetting, pagination and proofreading process, which may lead to differences between this version and the Version of Record. Please cite this article as: Öztürk Z. Diabetes, Oxidative Stress and Endothelial Dysfunction. Bezmialem Science 2018. DOI: $10.14235 /$ bs. 2018.2145

(C) Copyright 2018 by Bezmialem Vakif University - Available online at www.bezmialemscience.org 


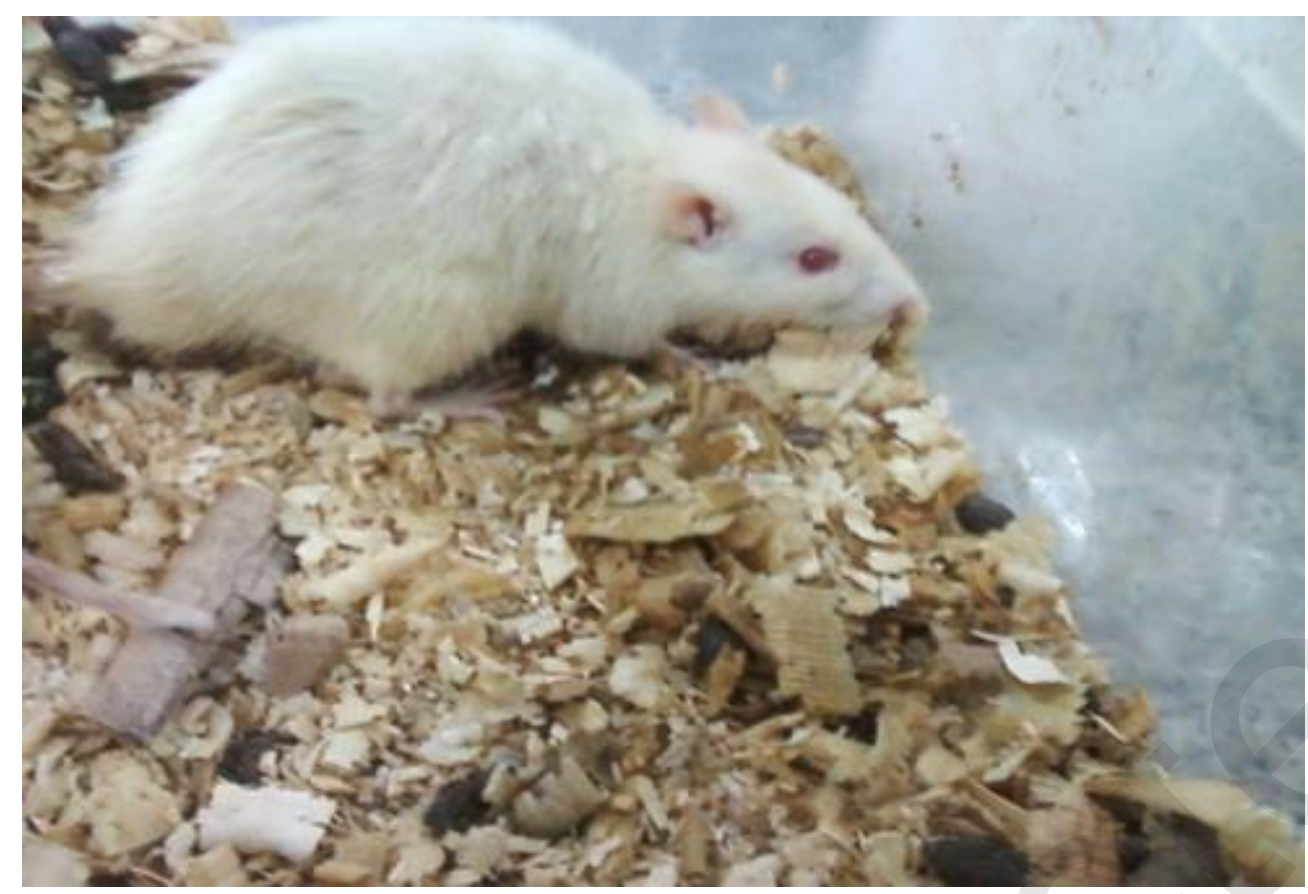

Şekil 1.2 Normal sıçan dış görünüşü

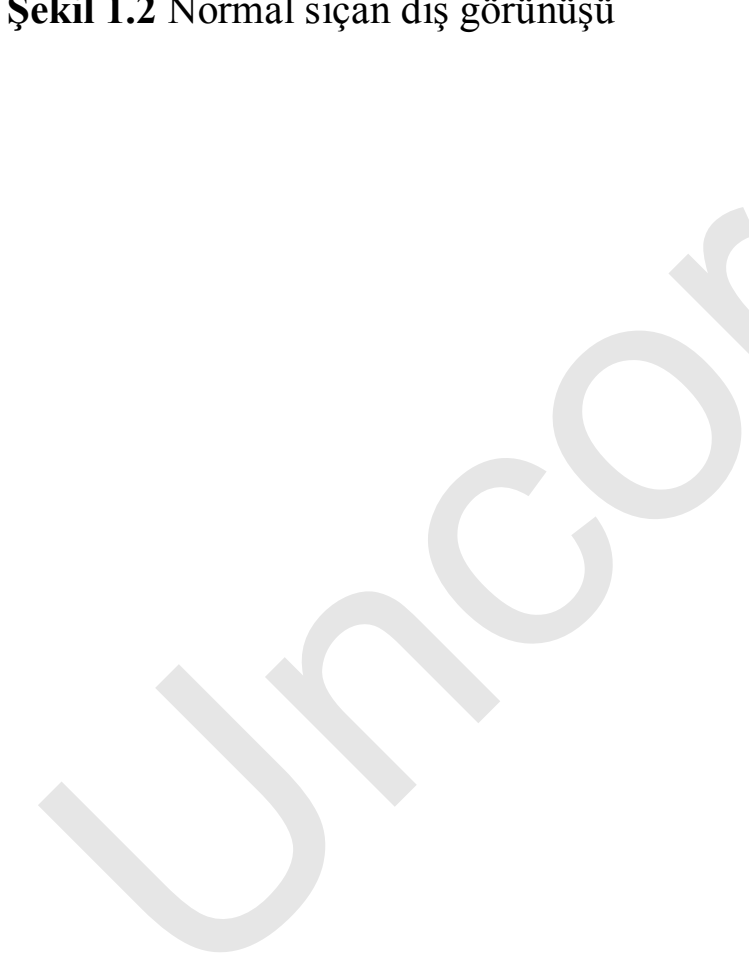

This article has been accepted for publication and undergone full peer review but has not been through the copyediting, typesetting, pagination and proofreading process, which may lead to differences between this version and the Version of Record. Please cite this article as: Öztürk Z. Diabetes, Oxidative Stress and Endothelial Dysfunction. Bezmialem Science 2018. DOI: $10.14235 /$ bs.2018.2145

CCopyright 2018 by Bezmialem Vakif University - Available online at www.bezmialemscience.org 